\title{
KNOWLEDGE, ATTITUDE AND PRACTICES TOWARDS HOUSEHOLD WASTE MANAGEMENT IN KAIPARAMBU PANCHAYAT OF THRISSUR DISTRICT, KERALA.
}

\section{Charles Chacko Porathoor*}

Dr. Jose Vincent
Medical student, Amala Institute of Medical Sciences, Amala Nagar, Thrissur-680 555, Kerala, India. ${ }^{*}$ Corresponding Author

Assistant Professor, Department Of Community Medicine,Amala Institute Of Medical Sciences, , Amala Nagar, Thrissur-680 555, Kerala, India.

ABSTRACT BACKGROUND: The topic of environmental protection has attained highest importance in this era globally but the practices of basic concepts of waste disposal are often neglected. 125 households from a rural area were selected as the study population. The study reveals the necessity of awareness among the people of proper waste disposal and management. OBJECTIVES: To assess the Knowledge, Attitude and Practices regarding household waste disposal among people in the Kaiparambu panchayat. METHODOLOGY: 125 households of the Kaiparambu panchayat of Thrissur, Kerala were included in the study. The sampling method used in the study was Simple Random Sampling. Interviewer administered questionnaire was used to obtain data on Knowledge, attitude and practice regarding household waste management in kaiparambu grama panchayat. RESULTS: Out of 125 households, the interviewer administered questionnaire was answered by $63(50.4 \%)$ females and 62(49.6\%) males. About $101(80.8 \%)$ people don't know about the principle of waste minimization. Only $58(46.4 \%)$ people know about the segregation of waste. About $88(70.2 \%)$ people throw their household wastes outside the home. About $103(82.3 \%)$ people believe banning plastic as a method for plastic waste management.

\section{KEYWORDS : Waste Management, Plastic Waste Management.}

\section{INTRODUCTION}

The topic of environmental protection has attained highest importance in this era globally but the practices of basic concepts of waste disposal are often neglected. People around the globe are aware of the impact of improper waste disposal practices, but the negative attitude of implementation gives rise to chaotic situations.? Improper waste disposal causes breeding and may cause infectious diseases like cholera, small pox, and plague, etc. 'The study reveals the necessity of awareness among the people of proper waste disposal and management.

Population is increasing all over the world, especially in developing countries. Similarly, increased amount of household waste is being produced by this growing population. Facilities to manage this waste are limited all over the globe, especially in developing countries, where these are minimal ${ }^{1}$. Solid Waste Management (SWM) has 3 basic components namely collection, transportation and disposal. Comprehensive solid waste management incorporates a diverse range of activities including reduction, recycling, segregation, modificationon, treatment and disposal which have varying levels of sophistication $^{2}$. The objective of SWM is to reduce the quantity of solid waste disposed off on land by recovery of materials and energy from solid waste in a cost effective and environmental friendly manner ${ }^{3}$.Environmental problems are many, it is mounting high with new problems like disposal of e-waste. E-waste is a collective terminology for the entire stream of electronic equipment such as TV, refrigerators, telephones, air conditioners, computers, mobile phones etc. that has reached its End of Life (EOL) for its current user. Such devices are generally considered toxic when disassembled or incinerated and are typically targeted for hazardous disposal or are slated for necessary recovery and reuse ${ }^{3}$.It is estimated that $1,60000 \mathrm{MT}$ (Metric Tonne) of municipal solid waste is generated daily in India. According to the 2001 census, per capita waste generation in India is $0.5 \mathrm{Kg} / \mathrm{day}^{4}$. Kerala is estimated to be churning out in excess of 8000 tons of garbage every day, of which $7 \%$ is plastic waste, and every town and city is now struggling to manage the solid waste that keep piling up with few options available to dispose them. Waste management activities generate potential environmental benefits if managed properly". Appropriate waste disposal Generally, a majority of the respondents $(60.0 \%)$ had an overall moderate level of knowledge about environmental sanitation with only less than one quarter $(22.9 \%)$ having an overall good level of knowledge ${ }^{6}$. There has hardly been any effort in the past to create community awareness, either about the likely perils due to poor waste management or the simple steps that every citizen can take. This could have helped in reducing waste generation and promote effective waste management. But this scenario has changed. Nowadays more and more people are taking interest in environmental issues, as they have started to experience the ill-effects of ecological issues ${ }^{7}$. Now environmental education is welcomed by all categories of people. It is an attempt to reorient education so that environmental competence is restored as one of its basic aims along with personal and social competence ${ }^{8}$.Hygiene starts from home, our household waste accounts for major amount of solid rubbish. Some are reusable and others non-reusable. All these constitute megatons of municipal wastes. If it is not properly disposed off, the consequences are dangerous ${ }^{9}$.It is important that the people of Kerala understand and change their attitude and practice towards waste management. This study was done to check what was the attitude, awareness and practice of the people in Thrissur district towards waste management.

\section{MATERIALS AND METHOD}

A Cross sectional study was conducted among the households of the Kaiparambu panchayat of Thrissur, Kerala. The 125 households in Thrissur district was taken as the sample size. The sample size was calculated using the formulae $4 \mathrm{PQ} / \mathrm{d}^{2}$ where $\mathrm{P}$ is the proportion of people who know about the effective mechanism for house hold waste management as $68 \%$ done in a previous study in Thrissur, Kerala, the calculated minimum sample size was 125 . The sampling technique used was simple random sampling. The data was collected by Interviewer administered questionnaire to obtain data on Knowledge, attitude and practice regarding household waste management in Kaiparambu grama panchayat. Inclusion and exclusion criteria were used in this study .The Data was entered into Excel sheet. The categorical variables were expressed as proportions and quantitative variables were expressed as mean and standard deviation. The Analysis of data was done using appropriate statistical software .The Study was conducted between August 2019 to September 2019. TheInstitutional ethics committee clearance was obtained and Informed consent was obtained from the participants. Confidentiality was ensured and maintained throughout the study. Approval was taken from stake holders of rural area. Informed Written consent was taken from people of rural area.

\section{RESULTS}

Out of 125 households, the interviewer administered questionnaire was answered by $63(50.4 \%)$ females and $62(49.6 \%)$ males.

Table 1- Knowledge Related Questions Asked By The Interviewer About Household Waste Management.

\begin{tabular}{|l|l|l|l|}
\hline S.No & Questions & Yes & No \\
\hline 1. & $\begin{array}{l}\text { Did you ever attend any awareness } \\
\text { programme conducted by local } \\
\text { authority house hold waste } \\
\text { management? }\end{array}$ & $21.6 \%(27)$ & $78.4 \%(98)$ \\
\hline 2. & $\begin{array}{l}\text { Do you know the principle of waste } \\
\text { minimization? }\end{array}$ & $19.2 \%(24)$ & $80.8 \%(101)$ \\
\hline
\end{tabular}


Volume - 10 | Issue - 11 | November - 2020 | PRINT ISSN No. 2249 - 555X | DOI : 10.36106/ijar

\begin{tabular}{|l|l|l|l|}
\hline \hline 3. & $\begin{array}{l}\text { Do you think that local authorities } \\
\text { have a role to play in the } \\
\text { management of house hold waste? }\end{array}$ & $98.4 \%(123)$ & $1.6 \%(2)$ \\
\hline 4. & $\begin{array}{l}\text { Do you know about segregation of } \\
\text { waste? }\end{array}$ & $46.4 \%(58)$ & $53.6 \%(67)$ \\
\hline 5. & $\begin{array}{l}\text { Do you know the effective } \\
\text { mechanism for house hold waste } \\
\text { management? }\end{array}$ & $62.1 \%(77)$ & $37.9 \%(48)$ \\
\hline 6. & $\begin{array}{l}\text { Do you know the complications of } \\
\text { improper waste management? }\end{array}$ & $82.3 \%(102)$ & $17.7 \%(23)$ \\
\hline 7. & Are you aware of e-waste? & $54.4 \%(68)$ & $45.6 \%(57)$ \\
\hline 8. & $\begin{array}{l}\text { Do you know how to dispose the e- } \\
\text { waste? }\end{array}$ & $84 \%(105)$ & $16 \%(20)$ \\
\hline 9. & $\begin{array}{l}\text { Do you think burning plastic wastes } \\
\text { causes health hazards? }\end{array}$ & $94.4 \%(118)$ & $5.6 \%(7)$ \\
\hline
\end{tabular}

Table 2 - Attitude Related Questions Asked By The Interviewer About Household Waste Management.

\begin{tabular}{|l|l|l|l|}
\hline S.No & Questions & Yes & No \\
\hline 1. & $\begin{array}{l}\text { Are you committed to minimize the } \\
\text { waste? }\end{array}$ & $73.6 \%(92)$ & $26.4 \%(33)$ \\
\hline 2. & Do you segregate house hold wastes? & $40.8 \%(51)$ & $59.2 \%(74)$ \\
\hline 3. & $\begin{array}{l}\text { Do you use kitchen waste as } \\
\text { compost? }\end{array}$ & $44 \%(55)$ & $56 \%(70)$ \\
\hline 4. & $\begin{array}{l}\text { Do you throw your household waste } \\
\text { outside your home? }\end{array}$ & $29.8 \%(37)$ & $70.2 \%(87)$ \\
\hline 5. & $\begin{array}{l}\text { Do you carry a shopping bag to do } \\
\text { grocery shopping? }\end{array}$ & $65.9 \%(81)$ & $34.1 \%(44)$ \\
\hline
\end{tabular}

Table 3 - Practice Related Questions Asked By The Interviewer About Household Waste Management.

\begin{tabular}{|l|l|l|l|}
\hline S.No & Questions & Yes & No \\
\hline 1. & $\begin{array}{l}\text { Is improper waste disposal is a } \\
\text { threat to environment? }\end{array}$ & $100 \%(125)$ & $0 \%(0)$ \\
\hline 2. & $\begin{array}{l}\text { Is household waste management is } \\
\text { the sole responsibility of local self- } \\
\text { governments? }\end{array}$ & $56.8 \%(71)$ & $43.2 \%(54)$ \\
\hline 3. & $\begin{array}{l}\text { Do you think burning is an } \\
\text { effective method of waste disposal? }\end{array}$ & $91.1 \%(113)$ & $8.9 \%(12)$ \\
\hline 4. & $\begin{array}{l}\text { Are you responsible for the } \\
\text { generation of house hold waste? }\end{array}$ & $52 \%(65)$ & $48 \%(60)$ \\
\hline 5. & $\begin{array}{l}\text { Do you have a role to minimize the } \\
\text { house hold waste? }\end{array}$ & $98.4 \%(123)$ & $1.6 \%(2)$ \\
\hline 6. & $\begin{array}{l}\text { Do you think banning plastic is a } \\
\text { viable method to curb plastic } \\
\text { pollution? }\end{array}$ & $82.3 \%(102)$ & $17.7 \%(23)$ \\
\hline
\end{tabular}

Only $21.6 \%$ (27) people has attended awareness programme and 78.4 $\%(98)$ has not attended awareness programme conducted by local authority on household waste management. About $19.2 \%$ (24) people know and $80.8 \%(101)$ don't know about the principle of waste minimization. About 98.4\% (123 )people believe and 1.6\% (2) people don't believe that local authorities have a role to play in the management of household waste .About 46.4\% (58)people know and $53.6 \%(67)$ people don't know about the segregation of waste. About $62.1 \%$ (77) people don't know and $37.9 \%$ (48) people know about the effective mechanism ofhousehold waste management.

\section{COMMITMENT TO MINIMIZE THE WASTE.}

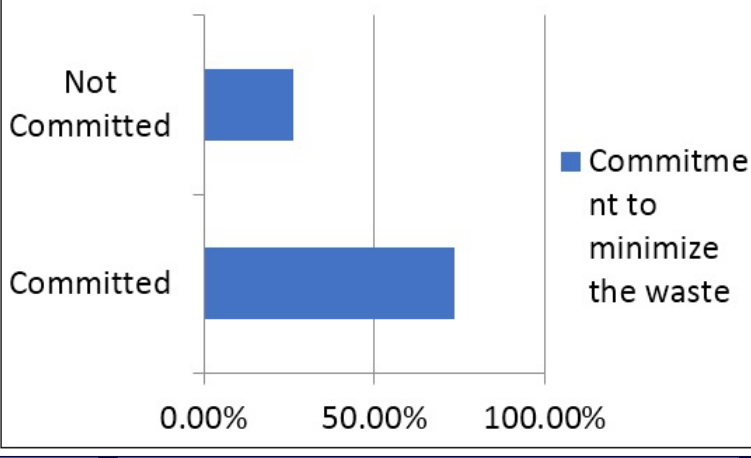

Percentage of people that know about effective house hold management

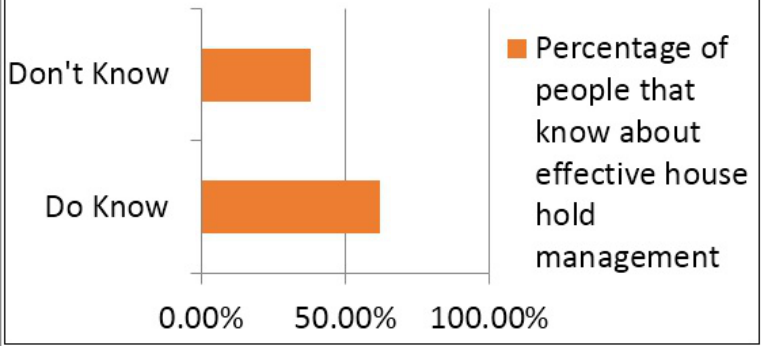

About $82.3 \%$ (102) people know and $17.7 \%$ (23) people don't know the complications of improper waste management. About $54.4 \%$ (68) people don't have an idea while $45.6 \%(57) \quad$ people have an idea about e-waste. About 84\% (105) people don't know and 16\% (20) people know how to dispose e-waste. About $94.4 \%$ (118) people think and 5.6\% (7) people don't think burning plastic wastes causes health hazards. About $73.6 \%$ (92) people are committed and $26.4 \%$ ( 33) people are not committed to minimize the waste.

About 40.8\% (51) people don't segregate while 59.2\%(74) people segregate their house hold waste. About 44\% (55) people don't use and $56 \%$ (70) people use their kitchen waste as compost. About 29.8\% (37) people throw and $70.2 \%(87)$ people don't throw their household waste outside their homes. About $65.9 \%$ (81) people carry and $34.1 \%(44)$ people don't carry a shopping bag to do grocery shopping. All the people that is $100 \%$ (125) of them think improper waste disposal as a threat to the environment. About $56.8 \%(71)$ people think and $43.2 \%$ 54) people don't think that household waste management is the sole responsibility of local self governments. About $91.1 \%$ (113) people believe and $8.9 \%$ (12) people don't believe that they are responsible for the generation of house hold waste. About 52\% (65) of the people think and $48 \%(60)$ people don't think burning is an effective method of waste disposal.

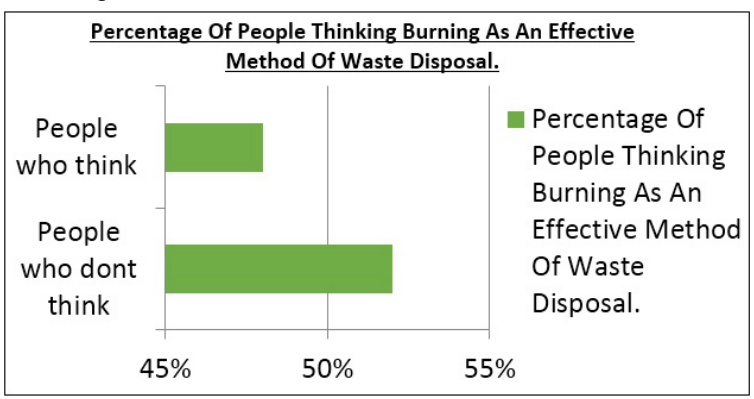

About $98.4 \%$ (123) people believe and 1.6\%(2) don't believe that they have a role to minimize the house hold waste. About $82.3 \%(102)$ people think and $17.7 \%$ (23) people don't think banning plastic is a viable method to curb plastic pollution.

\section{DISCUSSION}

A large amount of solid wastes are generated from homes. Household waste is a major source of solid waste. The quantity of solid waste grows faster than population ${ }^{4}$. Solid waste disposal has been identified as a major cause of pollution and environmental threat globally and very specially to God's own country, Kerala. In spite of the higher literacy rate and well developed educational systems and status in the state, there is lack of knowledge and practicing of proper waste management among Keralites, whether young or old. ' Only $21.6 \%$ (27) people has attended awareness program and 78.4\%(98) has not attended awareness program conducted by local authority on household waste management. About 19.2\% (24) people know and $80.8 \%(101)$ don't know about the principle of waste minimization. The findings of the present study have made it clear that they are not well aware of waste management. But about $82.3 \%$ (102) people know and $17.7 \%$ (23) people don't know the complications of improper waste management. This was seen in a similar study done in Lahore, Pakistan were Majority of respondents $(72.0 \%)$ was aware about adverse effects of improper waste management and $(28.0 \%)$ respondent was not aware about the above. Another finding in the study is that about $52 \%$ (65) of the people think and $48 \%(60)$ people don't think burning is an effective method of waste disposal. From this we 
can conclude that they are lacking in the practice of proper waste management. It is an environmental abuse to be corrected at the earliest if we want to save the mother earth. ${ }^{7}$ Present study showed that there is a serious lack of awareness about e-wastes and its management among both the groups. About $54.4 \%$ (68) people don't have an idea while $45.6 \%(57) \quad$ people have an idea about e-waste. This also was stated in a similar study in Thrissur in which $143(48 \%)$ was aware and 157 $(52 \%)$ was not aware about e waste ${ }^{7}$. In this era of cybernetics, young generation is being influenced by cyberphilia. As a result, worldwide ewastes are generated uncontrolled and unchecked. As of March 2009, approximately 4, 00,000 tons of e-wastes are produced in India. 19,000 tons of this comes from Mumbai, the largest e-waste generator in the country ${ }^{3}$. E-waste is the fastest growing segment of the solid wastes in India (0.01-1\%). This rate is growing at an alarming pace and a high percentage of electronics are ending up in the waste stream releasing dangerous toxins into the environment. ${ }^{7}$ So it is the need of the time to review this serious situation. With collective efforts from the part of government, educational institutions and NGOs, proper guidance can be given in this neglected area of waste management. It is the birth right of every citizen to live in a pollution free environment, to get good air to breathe and to have safe water to drink. As long as these basic rights are denied or a conducive atmosphere is not created, a nation cannot claim of its amazing and sustainable development.

\section{CONCLUSION}

In conclusion giving social duty awareness along with waste management awareness may improve the knowledge, attitude and practice of waste management. Awareness program of waste management is greatly needed for all the people in the community as only $21.6 \%$ (27) people has attended awareness programs conducted by local authority on household waste management. The awareness about e-wastes should be told to the people in the community because about $54.4 \%$ (68) people don't have an idea about e-waste in this particular study. The right attitude can be developed in the schools for the young generation and to the older generation in community based programs. For this purpose, government of the states/ country can implement environmental education programs. About 52\% (65) of the people think burning is an effective method of waste disposal so the right practice can be taught via programmes and through other visual media.

\section{ACKNOWLEDGEMENTS}

We are grateful to Department of Community Medicine of Amala Institute of Medical Sciences, Thrissur, Kerala.

\section{REFERENCES}

1. Shahzadi A, Hussain M, Afzal M, Gilani SA. Determination the Level of Knowledge, Shahzadi A, Hussain M, Afzal M, Gilani SA. Determination the Level of Knowledge,
Attitude, and Practices Regarding Household Waste Disposal among People in Rural Community of Lahore. Int J Soc Sci Manag. 2018 Jul 27;5(3):219-24.

2. Zagozewski R, Judd-Henrey I, Nilson S, Bharadwaj L. Perspectives on Past and Present Waste Disposal Practices: A Community-Based Participatory Research Project in Three Saskatchewan First Nations Communities. Environ Health Insights. 2011 Apr 28;5:9-20.

3. Ministry of Finance (MF). Position Paper on the Solid Waste Management Sector in India. Department of Economic affairs, Ministry of Finance, Government of India. India. Department of Economic affairs, Ministry of Finance, Government of India.
Minist Finance MF 2009. 2009;

4. Vinod, A., and Venugopal, K. Environmental Studies. 1st Ed Calicut Univ Cent Co-op Stores LTD No 4347. 2010;

5. Gentil E, Clavreul J, Christensen TH. Global warming factor of municipal solid waste management in Europe. Waste Manag Res. 2009 Nov 1;27(9):850-60.

6. Adogu POU, Uwakwe KA, Egenti NB, Okwuoha AP, Nkwocha IB. Assessment of Waste Management Practices among Residents of Owerri Municipal Imo State Nigeria. J Environ Prot. 2015 Apr 30;06(05):446.

7. Licy C, Raghavan V, Saritha K, Anies T, Josphina C. Awareness, Attitude and Practice of School Students towards Household Waste Management. Jouranal Environmment. 2013 Jan 1;02:147-50.

8. S.m S, B O, N.n P. A Comparative Study Of Environmental Awareness Among Secondary School Students In Iran And India. 2007 Jan 1;1(1):28-34.

9. Yadav PR, Mishra SR. Environmental Ecology. Discovery Publishing House; 2004. 376 p.

10. Ifegbesan A. Exploring Secondary School Students' Understanding and Practices of Waste Management in Ogun State, Nigeria. Int J Environ Sci Educ. 2010 Apr;5(2):201-15.

11. Harikrishnan, G. (2014). Solid waste management: A comparative study between Kerala and Tamil Nadu. International Journal of Research in Social Sciences and Humanities, $4(4), 32-36$. 